\title{
APHID SPECIES ON POTATO CROPS IN CANTERBURY
}

\author{
M.A.W. STUFKENS and D.A.J. TEULON \\ New Zealand Institute for Crop \& Food Research Limited, Private Bag 4704, \\ Christchurch, New Zealand \\ Corresponding author: stufkensm@crop.cri.nz
}

\begin{abstract}
A survey of aphids infesting table, processing and seed potato crops was undertaken in Canterbury during the 1999-2000 season (NovemberMarch). The green peach aphid (Myzus persicae (Sulzer)) was the most common aphid found on potato plants ( $>85 \%$ of all aphids), followed by the foxglove aphid (Aulacorthum solani (Kaltenbach)) and the potato aphid (Macrosiphum euphorbiae (Thomas)). These three aphids are vectors of the potato leaf roll virus (PLRV) and other potato viruses. A further eight species were found in low numbers including five species that are vectors of potato viruses (not PLRV). The melon aphid (Aphis gossypii Glover), was found in sizable numbers on sprayed potatoes in the Hawke's Bay. This species, which is known to have developed resistance to some insecticides on other crops in New Zealand, was found in only low numbers in three crops in Canterbury.
\end{abstract}

Keywords: green peach aphid, potato, aphid survey, potato virus.

\section{INTRODUCTION}

Aphids are important pests of potato crops in New Zealand. They damage plants directly by feeding and indirectly through the transmission of viruses. The management of virus is fundamental to potato production and is based on the planting of virus-free seed potato tubers of which $95 \%$ are produced in Canterbury (R. Genet, pers. comm.). Virus-free seed potatoes are produced under an insecticide regime for aphid vector control, which includes seed treatments, and up to six foliar applications. In recent years, however, there has been a notable increase in the level of the potato leaf roll virus (PLRV) (transmitted only by aphids) in seed potato crops in Canterbury (Fletcher 1997; Wright 1997; Teulon et al. 2001). To help growers determine the risk of virus infection and to plan for the timing of pesticide applications, a suction trap programme which monitors the flight activity of virus-transmitting aphids is being developed by Crop \& Food Research in partnership with the potato industry (Stufkens et al. 2000; Teulon et al. 2001). Understanding the species composition and relative abundance of virustransmitting aphid species (especially PLRV vectors) in potato crops will help to determine which aphid species should be monitored in the suction traps.

A review of international and national literature has identified up to 28 aphid species as actual or potential vectors of up to seven potato viruses in New Zealand (D.A.J. Teulon, unpubl. data; Fletcher 1997). Nine of these are PLRV vectors. In New Zealand the aphid fauna of potato crops has been dominated by three species, the green peach aphid Myzus persicae (Sulzer), the foxglove aphid Aulacorthum solani (Kaltenbach), and the potato aphid Macrosiphum euphorbiae (Thomas) (Cottier 1931; Watts 1953; Close 1965; Till 1971; Miln 1978; Webby 1988). All are vectors of PLRV and other potato viruses. The relative abundance of these species has varied between studies with numbers of the green peach aphid increasing and the foxglove aphid decreasing in relation to other species in relatively recent studies (Till 1971; Webby 1988).

In the latest New Zealand survey the melon aphid Aphis gossypii Glover was implicated as a coloniser of potatoes in Canterbury (Webby 1988). This aphid is a vector of several potato viruses but not PLRV. It has become an important pest of potatoes in Europe

New Zealand Plant Protection 54:235-239(2001) 
where it has become resistant to some insecticides (Rongai et al. 1998). Insecticideresistant melon aphid populations have been found on chrysanthemum in New Zealand (Martin \& Workman 1997) and there are reports of sizable melon aphid populations in recently sprayed potatoes in the Hawke's Bay (T. Herman, pers. comm.).

The main aim of this work was to confirm the species composition and relative abundance of aphid species on potato crops in Canterbury.

\section{METHODS}

Field surveys for aphids infesting potato crops in Canterbury were undertaken in the 1999-2000 growing season. Ten table, two processing and four seed crops, encompassing a range of potato varieties and insecticide regimes were selected (Table 1). Crops were sampled for aphids on one to five occasions from November 1999 to March 2000. Each sample consisted of a $0.5 \mathrm{~h}$ search of the leaves of a potato crop by walking in a W pattern through the crop, as well as sampling the edges of the paddock. Leaves on all positions of potato plants were examined and all aphids found were collected. Weeds in and around the crops were also sampled at the same time, both within the crop and along fence lines. The field incidence of aphid predators and mummified (parasitised) aphids as observed on potato leaves were recorded.

In the laboratory, winged and wingless aphids were differentiated (wingless adults and immatures were not distinguished) and identified to species under a stereo binocular microscope using the keys of Teulon (1999) and Teulon et al. (1999). Immature aphids were identified by taking into account their proximity and similarity to the adults they were collected with.

TABLE 1: Location, cultivar, market, insecticide treatment and month of sample of 16 potato crops sampled for aphids in Canterbury, 1999-2000.

\begin{tabular}{lllll}
\hline Location & Cultivar & Market for crop & $\begin{array}{l}\text { Insecticide } \\
\text { treatment }\end{array}$ & Month of sample \\
\hline Kaiterete & mixed & Table & untreated & Dec \\
Harewood & mixed & Table & untreated & Nov, Dec, Jan, Feb \\
Avoca & mixed & Table (organic) & untreated & Nov \\
Overdale & Shepardy & Processing & untreated & Nov, Dec, Jan, Feb \\
Chertsey & Russett & Table & untreated & Nov, Dec, Jan, Feb, Mar \\
Chertsey & Ranger & Processing & untreated & Nov, Dec, Jan, Feb, Mar \\
Halswell & mixed & Table & foliar & Nov, Dec \\
Kimberley & Agria & Seed & foliar & Dec, Jan, Feb, Mar \\
Kimberley & Lisetta & Table & foliar & Dec \\
West Melton & Agria & Seed & soil & Dec \\
Aylesbury & Agria & Seed & soil & Dec, Jan, Feb, Mar \\
Aylesbury & Fianna & Seed & soil & Dec, Jan, Feb, Mar \\
Dunsandel & Draga & Table (export) & soil & Nov, Dec, Jan \\
Aylesbury & Nadine & Table & seed & Nov, Dec \\
Aylesbury & Nadine & Table & foliar & Jan, Feb \\
Aylesbury & Russett & Table & seed & Dec, Jan, Feb \\
\hline
\end{tabular}

\section{RESULTS AND DISCUSSION}

Aphids on potatoes

Most aphids were found on the lower leaves of the potato plants, with very few found on the middle to upper leaves. The green peach aphid was by far the most common aphid species collected, contributing over $85 \%$ of aphids sampled, followed by the 
foxglove aphid and the potato aphid (Table 2). Together these three aphids contributed over $96 \%$ of all the aphids identified. All three species produced aphid colonies on the potato crops.

TABLE 2: Total numbers of aphids found on 16 potato crops sampled in Canterbury from November 1999 to March 2000. The first value in each column is winged adults and the second value is the total of wingless adults and immatures combined.

\begin{tabular}{lcccccc}
\hline $\begin{array}{l}\text { Aphid } \\
\text { species }\end{array}$ & $\begin{array}{c}\text { Nov } \\
(\mathrm{n}=8)\end{array}$ & $\begin{array}{c}\text { Dec } \\
(\mathrm{n}=14)\end{array}$ & $\begin{array}{c}\text { Jan } \\
(\mathrm{n}=10)\end{array}$ & $\begin{array}{c}\text { Feb } \\
(\mathrm{n}=9)\end{array}$ & $\begin{array}{c}\text { Mar } \\
(\mathrm{n}=5)\end{array}$ & $\begin{array}{c}\text { Total } \\
(\mathrm{n}=46)\end{array}$ \\
\hline Green peach & $76 / 175$ & $27 / 89$ & $2 / 34$ & $21 / 300$ & $42 / 437$ & $168 / 1035$ \\
Foxglove & $16 / 95$ & $0 / 13$ & $0 / 0$ & $0 / 0$ & $0 / 0$ & $16 / 108$ \\
Potato & $9 / 18$ & $2 / 0$ & $0 / 0$ & $0 / 4$ & $2 / 8$ & $13 / 30$ \\
Melon & $0 / 1$ & $0 / 0$ & $0 / 1$ & $0 / 3$ & $0 / 0$ & $0 / 5$ \\
Others & $13 / 13$ & $4 / 3$ & $0 / 0$ & $0 / 1$ & $0 / 0$ & $17 / 17$ \\
Total & $114 / 302$ & $33 / 22$ & $2 / 35$ & $21 / 308$ & $44 / 445$ & $214 / 1195$ \\
\hline
\end{tabular}

${ }^{1} \mathrm{n}=$ number of crops sampled for a given month.

The green peach aphid was found on all but two of the sixteen crops sampled and on one occasion 369 were found in a $0.5 \mathrm{~h}$ search. The foxglove aphid was found on four of the crops sampled, mainly in the market gardening area around Christchurch, and was associated with weedy crops. The potato aphid was found on five crops associated with table/processing production, rather than seed production, and in weedy crops.

A further eight aphid species were found in smaller numbers than the three main aphid species, on only a few crops. The melon aphid (five wingless, three of which were in one crop), a vector of about five potato viruses but not PLRV, was found on three crops. Interestingly, samples of potatoes in Halswell had no melon aphids on them despite being $20 \mathrm{~m}$ from outdoor chrysanthemum and lily crops hosting large numbers of melon aphids. Moreover, there have been control failures with insecticides for melon aphids on these chrysanthemums and lilies in the last 3 years (M. Stufkens, unpubl. data). Conversely, the melon aphid has been recorded in large numbers on two separate table potato crops in autumn 2000 and in one crop in 2001 in the Hawke's Bay (T. Herman, pers. comm.). These crops had received up to six insecticide applications, the latest ones being, at most, 7 days before the aphids were observed. These observations suggest that the insecticides used on those Hawke's Bay potato crops were not effective at controlling the melon aphid (T. Herman, pers. comm.). It is hoped to measure the response of a melon aphid population from these Hawke's Bay crops to various insecticides in laboratory bioassays in the near future. Indeed, the melon aphid has recently become an important pest of potatoes in Europe where it has shown some insecticide resistance (Rongai et al. 1998). While in the past the melon aphid was not common on potatoes in New Zealand, further monitoring of this species is very important to define its pest status. A resistance management strategy is also a priority to delay the development of insecticide resistance of this aphid in New Zealand.

The carrot aphid Cavariella aegopodii (Scopoli) (nine winged, five wingless including immatures), a vector of potato virus $\mathrm{Y}^{\mathrm{N}}$, was only found in a weedy unsprayed crop at Harewood. This crop was close to a willow shelter belt, which is the overwintering host for this insect (Blackman \& Eastop 2000). The pea aphid Acyrthosiphum pisum (Harris) (one winged, six wingless including immatures), a vector of PLRV, potato virus $\mathrm{Y}^{\mathrm{N}, \mathrm{O}}$, potato virus A and potato virus S, was found in one organic crop at Avoca Valley where the potatoes were interspersed between different vegetable crops. One immature ornate aphid Myzus ornatus (Laing), a vector of PLRV and potato virus Y, was found on each 
of two separate table crops that had severe weed infestations. The leaf-curling plum aphid Brachycaudus helichrysi (Kaltenbach) (3 winged, 2 wingless including immatures), a vector of potato virus $\mathrm{Y}^{\mathrm{N}, \mathrm{O}}$ and potato virus $\mathrm{A}$, was collected from three different crops. In large numbers this species can be an important vector of potato virus $Y$ even though it does not colonise potatoes (Blackman \& Eastop 2000). The other aphids collected were transient winged adults of the cabbage aphid Brevicoryne brassicae (L.) (three), Capitophorus elaeagni (del Guercio) (one) and Uroleucon sonchi (L.) (one). These species are not known to transmit potato viruses.

Crops were not selected to compare differences in aphid numbers between locations, cultivars or pest management regimes, but to ensure that a representative sample of aphid species was obtained on a wide variety of potato crops and regimes. Nevertheless some general observations on the effect of management practices on aphid numbers can be made. Aphid numbers were lowest on crops receiving insecticide applications and highest on untreated crops. Crops close to Christchurch, those with a high level of plant diversity (especially other vegetables) in close proximity and table potato crops, also had high aphid numbers.

In most seed crops sampled, aphid numbers never reached the critical threshold levels of 10 aphids per 100 leaves that are thought to warrant spraying (Fletcher \& Herman 2000). One positive consequence of the aphid survey was the substantial reduction in spray applications. On the four seed potato growing properties, there were 18 seed potato crops. Only one of these reached the critical threshold level and was sprayed. Without this information it is likely that all 18 crops would have been sprayed (M. Stufkens, pers. comm.).

\section{Seasonal differences}

All crops contained aphids at the first sample date in late November. Numbers declined during December and January and then increased appreciably in February and March.

Insecticides for aphid control are not normally applied after the destruction of the foliage by mowing and desiccation (burn-off) in seed crops in autumn. These crops are left in the ground for a few months before harvesting, during which time some re-growth and tuber sprouting can occur. We found sizeable numbers of winged and immature aphids on this new growth. In all four seed potato crops sampled, aphid colonies were observed on over $70 \%$ of the new growth. It has been suggested that most virus problems in seed potato crops in the Netherlands are the result of transmission occurring on regrowth after burn-off (Teulon 2001).

\section{Natural enemies}

Aphid predators, especially spiders, lacewings and parasitoids, were seen in all crops. In many of the crops, even those without insecticide applications, aphid numbers stayed below the threshold level throughout the season. These aphids were mainly found on the lower leaves where the majority of predators are located and these predators could have been responsible for keeping the aphid numbers low.

Aphids on weeds

The three main potato-infesting aphid species were also found on several weeds, especially nightshade (Solanum spp.) and fathen (Chenopodium album), within the surveyed potato crops. A number of weeds are known to be infected with potato viruses (Fletcher \& Herman 2000) and may act as a reservoir from which viruses may be transmitted to potatoes. However, aphids were not always found on weeds within the surveyed crops. Conversely, in one unsprayed crop at Harewood, all three major potatoinhabiting species were found heavily infesting large nightshade weeds throughout the potato crop, but few aphids were found on the potato plants. This crop was close to harvest and had begun to senesce. There were also large differences in the number of aphids on weedy seed potato crops after 'burn-off' in late summer.

Conclusion

The green peach aphid (in particular), the foxglove aphid and the potato aphid, were the most common aphids (>96\% of all species) on potato crops in Canterbury in 19992000. These three aphids are also the main vectors of PLRV, as well as transmitting 
other potato viruses, and should remain the key species monitored for the management of this virus. Another five aphid species, all vectors of other potato viruses (not PLRV), were found in small numbers. These may need to be taken into account in future monitoring programmes under certain conditions (e.g. large aphid flights, resistance development). The pest status of the melon aphid needs to be reviewed regularly.

\section{ACKNOWLEDGEMENTS}

This project was funded by the Potato Industry Research Development Grants Committee of the New Zealand Vegetable and Potato Growers Federation, AB Annand Ltd, Alex McDonald Merchants Ltd, Dawe's Produce Ltd, Eurogrow - a division of Wrightson seeds, McCains Foods Ltd, Robinson RG Produce Ltd and Technology New Zealand. We thank the growers for allowing us to sample their crops and for providing crop husbandry information.

\section{REFERENCES}

Close, R.C. 1965: Control of leaf roll virus in potatoes. Proc. $18^{\text {th }}$ N.Z. Weed and Pest Control Conf: : 197-246.

Cottier, W. 1931: An insect survey of potato foliage in New Zealand. N.Z. J. Sci. Tech. 3: 125-139.

Fletcher, J. 1997: Management of potato viruses. Commercial Grower 52 (10): 33-35.

Fletcher, J.; Herman, T. 2000: Management of potato viruses. Crop \& Food Research Broadsheet No. 104. Crop \& Food Research, Lincoln, New Zealand.

Lowe, A.D. 1967: Sowing date as an aphid-virus control technique. Proc. $20^{\text {th }}$ N.Z. Weed and Pest Control Conf:: 214-216.

Martin, N.A.; Workman, P.J. 1997: Melon aphid (Aphis gossypii) resistance to pesticides. Proc. 50th N.Z. Plant Prot. Conf.: 405-408.

Miln, A.J. 1978: Potato aphids in the Manawatu. Proc. 31st N.Z. Weed and Pest Control Conf: : 79-84.

Rongai, D.; Cerato, C.; Martelli, R.; Ghendini, R. 1998: Aspects of insecticide resistance and reproductive biology of Aphis gossypii Glover on seed potatoes. Potato Res. 41: 29-37.

Stufkens, M.A.W.; Teulon, D.A.J.; Nicol, D.; Fletcher, J.D. 2000: Implications of aphid flight patterns for pest management of potatoes. N.Z. Plant Prot. 53: 78-82.

Teulon, D.A.J. 1999: Illustrated multiple-entry key for winged aphids in New Zealand. Crop \& Food Research Report No. 614. Crop \& Food Research, Lincoln, New Zealand.

Teulon, D.A.J. 2001. Aphid/virus management. Grower 56 (2): 52-53.

Teulon, D.A.J.; Eastop, V.F.; Stufkens, M.A.W.; Harcourt, S.J. 1999: Illustrated multipleentry key for apterous aphids of economic importance in New Zealand. Crop \& Food Research Report No. 612. Crop \& Food Research, Lincoln, New Zealand.

Teulon, D.A.J.; Stufkens, M.A.W. 2001: The lack of a relationship between aphid virus vector activity and potato leaf roll virus incidence. N.Z. Plant Prot. 54: 229-234.

Till, B.B. 1971: The effect of insecticides on the spread of potato leaf roll virus in seed potato fields at Pukekohe. N.Z. J. Agric. Res. 14: 458-468.

Watts, B.B. 1953: The aphids of the potato crop. MSc thesis, University of New Zealand.

Webby, G.N. 1988: Study on the luteoviruses: potato leaf roll virus, beet western yellows virus and tomato yellow top virus. $\mathrm{PhD}$ thesis, Lincoln University, Canterbury, New Zealand.

Wright, Q. 1997: Potato sector off to a good start. Commercial Grower52 (7): 19. 